\title{
OBYWATELSKA INICJATYWA USTAWODAWCZA W POLSKIM PORZĄDKU PRAWNYM - PRÓBA OCENY Z PERSPEKTYWY PRAKTYKI PARLAMENTARNEJ
}

\section{UWAGI WPROWADZAJĄCE}

W konstytucjach państw demokratycznych prawo obywatelskiej inicjatywy ustawodawczej znajduje szczególne miejsce i pojmowane jest jako instrument wpływania na kształt ustawodawstwa, a w konsekwencji na proces wzmacniania społeczeństwa obywatelskiego ${ }^{1}$. Dzięki obywatelskiej inicjatywie ustawodawczej obywateli możliwe jest przedłożenie organowi ustawodawczemu projektu aktu normatywnego ${ }^{2}$. Prawo to przysługuje określonej grupie obywateli $^{3}$. Podzielić należy stanowisko Macieja Zielińskiego, że „Ratio legis istnienia obywatelskiej inicjatywy ustawodawczej stanowi teza, że jeżeli demokracja współczesna ze względu na rozmiary i rozmaitość funkcji współczesnego państwa ma mieć charakter demokracji przedstawicielskiej, to należy umożliwić społeczeństwu obywatelskiemu instrumenty oddziaływania na proces sprawowania władzy, w sposób inny aniżeli tylko poprzez wybór członków izb parlamentu, ewentualnie niektórych organów władzy wykonawczej”4.

Prawo inicjatywy ustawodawczej stanowić może również instrument w realizacji zasady ochrony zaufania obywatela do państwa i do prawa, określanej również jako zasada lojalności państwa wobec obywatela. W orzecznictwie Trybunału Konstytucyjnego podkreśla się, że zasada ta „wyraża się w takim

\footnotetext{
${ }^{1} \mathrm{Na}$ temat społeczeństwa obywatelskiego szerzej m.in.: B. Przywora, Kontrola społeczna $i$ społeczeństwo obywatelskie, w: R. Hauser, Z. Niewiadomski, A. Wróbel (red.) System prawa administracyjnego, t. 13: Etyka urzędnicza i etyka służby publicznej, Warszawa 2016, s. 251-255 i powoływana tam bogata literatura, w szczególności opracowania: H. Izdebskiego, L. Garlickiego, P. Sarneckiego, I. Niżnik-Dobosz.

${ }^{2}$ Podobnie m.in. M. Jabłoński, Obywatelskie prawo inicjatywy ustawodawczej, w: B. Banaszak, A. Preisner (red.), Prawa i wolności obywatelskie w Konstytucji RP, Warszawa 2002, s. $645-646$.

${ }^{3} \mathrm{~W}$ piśmiennictwie zob.: P. Uziębło, Inicjatywa ustawodawcza obywateli w Polsce na tle rozwiazań ustrojowych państw obcych, Warszawa 2006, s. 31 i n.; S. Grabowska, Formy demokracji bezpośredniej w wybranych państwach europejskich, Rzeszów 2009, s. 149 i n.; P. Chybalski, Komentarz do art. 118 Konstytucji, w: M. Safjan, L. Bosek (red.), Konstytucja RP, t. 2: Komentarz do art. 87-243, Legalis 2016 [dostęp: 9.11.2017].

${ }^{4}$ Por. M. Zieliński, Obywatelskie prawo inicjatywy ustawodawczej, w: M. Jabłoński (red.), Realizacja $i$ ochrona konstytucyjnych wolności i praw jednostki $w$ polskim porzqdku prawnym, Wrocław 2014, s. 485.
} 
stanowieniu i stosowaniu prawa, by nie stawało się ono swoistą pułapką dla obywatela i aby mógł on układać swoje sprawy w zaufaniu, iż nie naraża się na prawne skutki, których nie mógł przewidzieć w momencie podejmowania decyzji i działań oraz w przekonaniu, iż jego działania podejmowane zgodnie z obowiązującym prawem będą także w przyszłości uznawane przez porządek prawny. Przyjmowane przez ustawodawcę nowe unormowania nie moga zaskakiwać ich adresatów, którzy powinni mieć czas na dostosowanie się do zmienionych regulacji i spokojne podjęcie decyzji co do dalszego postępowania" ${ }^{5}$. Uzasadnione wydaje się twierdzenie, że ważnym elementem zasady ochrony zaufania obywatela do państwa i do prawa jest obowiązek poszanowania przez ustawodawcę interesów jednostek, które mogą być wyrażane w drodze inicjatywy ustawodawczej.

W artykule z jednej strony oceniono obowiązujace rozwiązania w zakresie obywatelskiej inicjatywy ustawodawczej wynikające z Konstytucji Rzeczypospolitej Polskiej z 2 kwietnia 1997 r. ${ }^{6}$ oraz z ustawodawstwa zwykłego, z drugiej zaś - podjęto próbę przeanalizowania przebiegu postępowań z obywatelskimi projektami na przykładzie VI i VII kadencji Sejmu RP. Wydaje się, że zgromadzony materiał może stanowić podstawę do pogłębionej analizy oraz formułowania wniosków końcowych co do kierunków zmian w zakresie obywatelskiej inicjatywy ustawodawczej ${ }^{7}$. Niniejszy artykuł wpisuje się również w ciag opracowań mających na celu podjęcie problemu optymalizacji trybu tworzenia prawa ${ }^{8}$.

${ }^{5}$ Wyrok TK z 7 lutego 2001 r., K 27/00, OTK ZU 2/2001, poz. 29; szerzej na temat zasady ochrony zaufania obywatela do państwa i do prawa jako elementów demokratycznego państwa prawnego: M. Zubik, W. Sokolewicz, Komentarz do art. 2 Konstytucji Rzeczypospolitej Polskiej, w: L. Garlicki, M. Zubik (red.), Konstytucja Rzeczypospolitej Polskiej. Komentarz, t. 1, Warszawa 2016, Lex/el. [dostęp: 9.11.2017].

${ }_{6}^{6}$ Dz. U. Nr 78, poz. 483 ze zm. (dalej jako: Konstytucja RP).

7 Niniejsze opracowanie jest kontynuacją rozważań podjętych w projekcie badawczym pt. „Zastosowanie metod statystycznych do ustalenia charakteru długookresowych tendencji występujących w procesie ustawodawczym”, pod kierownictwem prof. nadzw. dr. hab. P. Chmielnickiego, w ramach konkursu Narodowego Centrum Nauki „OPUS 5”, zrealizowanego w 2014 r. W ramach projektu dokonano kwerendy danych o przesłankach społeczno-gospodarczych stanowienia ustaw, obejmującej badanie dokumentów stwierdzających przebieg dyskusji parlamentarnej (uzasadnienia projektów, protokoły posiedzeń plenarnych obu izb parlamentu oraz komisji) oraz sporządzono opracowania zbiorczego, w którym została zawarta rekapitulacja ustaleń w zakresie skutków społeczno-gospodarczych, których osiagnięcie stawiano za cel każdej z ustaw. Opracowanie to stanowi także pogłębienie analiz w zakresie praktyki zastosowania przyspieszonego trybu stanowienia prawa, poczynionych w pracy: M. Borski, R. Glajcar, B. Przywora, Postepowanie ustawodawcze w polskim parlamencie-prawo, zwyczaje i praktyka, Sosnowiec 2015.

${ }^{8} \mathrm{~W}$ piśmiennictwie zob. m.in. opracowania: M. Borski, B. Przywora, Postęowanie z projektem pilnym jako przykład szczególnego trybu ustawodawczego w polskim porzadku prawnym - próba oceny z perspektywy praktyki parlamentarnej, „Przegląd Sejmowy” 2016, nr 4, s. 11-26; W. Orłowski, O potrzebie optymalizacji procesu ustawodawczego w Polsce, „Studia Iuridica Lublinensia” 2014, nr 22, s. 479 i przywoływana tam literatura m.in.: M. Zieliński, S. Wronkowska, O korespondencji dyrektyw redagowania i interpretowania tekstu prawnego, „Studia Prawnicze” 1985, z. 3-4; S. Wronkowska, M. Zieliński, Problemy i zasady redagowania tekstów prawnych, Warszawa 1993; J. Wróblewski, Teoria racjonalnego tworzenia prawa, Wrocław 1985. 


\section{WYBRANE REGULACJE PRAWNE UTRUDNIAJĄCE EFEKTYWNE KORZYSTANIE Z OBYWATELSKIEJ INICJATYWY USTAWODAWCZEJ}

Praktyka pokazuje, że istnieje wiele barier utrudniajacych obywatelom skuteczne korzystanie z prawa inicjatywy ustawodawczej. Pojawiają się one na każdym etapie - od rejestracji komitetu aż po etap prac parlamentarnych nad projektem. Są to czynniki wynikające zarówno z treści ustawy, jak i z praktyki parlamentarnej.

Wydaje się, że największym problemem dla obywateli chcacych skorzystać z prawa inicjatywy obywatelskiej jest zebranie w ciagu trzech miesięcy od dnia przyjęcia zawiadomienia przez Marszałka Sejmu i wydania przez niego postanowienia w tej sprawie brakujących co najmniej 99 tysięcy podpisów poparcia. W praktyce okazuje się, że problemem jest nie tyle zebranie odpowiedniej liczby podpisów, ile osiagnięcie tego w wyznaczonym czasie. Ten czas jest nierzadko za krótki dla grup obywateli nieposiadających rozległej sieci ochotników bądź wolontariuszy ${ }^{9}$. Dla komitetów, którym udało się złożyć w Sejmie swój projekt ustawy, największą barierą okazuje się natomiast zasada dyskontynuacji, która zamiast zostać całkowicie wyłączona w stosunku do projektów obywatelskich, została jedynie ograniczona do następnej kadencji Sejmu ${ }^{10}$. W praktyce oznacza to, że projekty nierozpatrzone w trakcie kadencji, w której zostały złożone, lub $\mathrm{w}$ następnej przepadają ostatecznie i prace nad nimi zostają zakończone ${ }^{11}$.

Warto w tym miejscu zauważyć, że nie zostały przewidziane żadne ułatwienia dotyczące uzasadnienia projektów obywatelskich. Tymczasem wydaje się, że uzasadnieniom projektów obywatelskich nie powinno się stawiać takich samych wymagań jak wnioskodawcom „profesjonalnym” wskazanym w art. 118 ust. 1 Konstytucji RP (posłom, Senatowi RP, Prezydentowi RP czy Radzie Ministrów), już chociażby z uwagi na fakt, że komitety tworzone przez obywateli sa podmiotami powoływanymi ad hoc i nie maja rozbudowanej struktury ani aparatu administracyjnego, jakimi dysponują np. Kancelarie Sejmu i Senatu RP ${ }^{12}$.

${ }^{9}$ Odmienne stanowisko prezentuje P. Uziębło, który zauważa, że termin ten mobilizuje komitet inicjatywy ustawodawczej do aktywnego działania. Jego zdaniem zbytnie rozciagnięcie czasowe kampanii mogłoby powodować swoiste rozprzężenie komitetu, a z drugiej strony również i dezorientować wyborców, gdyż po pewnym czasie mogliby oni tracić orientację, czy wsparli już dany projekt, czy też jest to już projekt odmienny. Zob. P. Uziębło, Demokracja partycypacyjna, Gdańsk 2009, s. 238.

10 Zgodnie z art. 4 ust. 3 ustawy z 24 czerwca 1999 r. o wykonywaniu inicjatywy ustawodawczej przez obywateli (Dz. U. Nr 62, poz. 688 ze zm.): „Projekt ustawy, w stosunku do którego postępowanie ustawodawcze nie zostało zakończone w trakcie kadencji Sejmu, w której został wniesiony, jest rozpatrywany przez Sejm następnej kadencji bez potrzeby ponownego wniesienia projektu ustawy. W takim wypadku Marszałek Sejmu zarządza ponowne drukowanie projektu ustawy oraz jego doręczenie posłom”.

11 Dotyczy to zarówno kadencji, które kończą się w konstytucyjnie zakreślonych terminach, jak i kadencji skróconych. Szerzej na ten temat zob. A. Szmyt, Elementy praktyki sejmowej pod rzqdami Konstytucji RP (1997-2007), Gdańsk 2008, s. 250-251.

12 Por. M. Borski, Inicjatywa ludowa jako instytucja dialogu społecznego, w: A. Kamińska, E. Kraus, K. Ślęczka (red.), Jak możliwy jest dialog?, Sosnowiec 2014, s. 61. 
Należy podkreślić, że wstępnej kontroli wniesionego projektu ustawy (w tym oczywiście projektu obywatelskiego) dokonuje Marszałek Sejmu. Gdy stwierdzi, że uzasadnienie nie odpowiada wymogom określonym $\mathrm{w}$ art. 34 ust. 2 i 3 regulaminu $\operatorname{Sejmu}^{13}$, może zwrócić wnioskodawcy (w tym również komitetowi inicjatywy ustawodawczej) projekt ustawy, a tym samym spowodować nieskuteczność wykonanej inicjatywy ustawodawczej. Podkreślić przy tym trzeba, że skorzystanie z tej kompetencji zależy wyłącznie od uznania Marszałka Sejmu. Gdy istnieja podstawy do zwrotu projektu ustawy wnioskodawcy, Marszałek nie musi tego czynić. Jak słusznie zauważa Grzegorz Koksanowicz: „Fakultatywność decyzji o zwrocie projektu ustawy wnioskodawcy, powoduje istotny wzrost roli tego organu. Swoboda interpretacyjna wynikajaca $\mathrm{z}$ charakteru prawnego tej kompetencji, jawi się z jednej strony jako istotny środek prawny, za pomoca którego można wpływać na jakość tworzonego prawa, z drugiej strony może stać się przyczyną niejednakowego traktowania wniesionych projektów ustaw. Można bowiem wyobrazić sobie sytuację, gdy np. dwa projekty ustaw nie odpowiadają wymogom regulaminowym, marszałek zaś w stosunku do jednego z nich podejmuje decyzję o zwrocie wnioskodawcy, a drugiemu nadaje bieg" ${ }^{14}$.

Wszystkie projekty ustaw (w tym projekty wniesione przez grupę co najmniej 100 tysięcy obywateli) są badane przez Marszałka Sejmu pod kątem zgodności proponowanych rozwiązań z prawem. Zgodnie z art. 34 ust. 8 regulaminu Sejmu projekt ustawy, co do którego istnieje wątpliwość, czy nie jest sprzeczny z prawem, w tym z prawem Unii Europejskiej lub podstawowymi zasadami techniki prawodawczej, może zostać skierowany przez Marszałka Sejmu po zasięgnięciu opinii Prezydium Sejmu do Komisji Ustawodawczej, celem wyrażenia przez nią opinii. Wydaje się, że powodem, dla którego wyposażono Marszałka Sejmu w tę kompetencję, było niedopuszczenie do sytuacji, gdy postępowanie ustawodawcze prowadzone jest w stosunku do projektu ocenionego jako niezgodny z prawem ${ }^{15}$. Wątpliwości te mogą mieć różne źródło, mogą wynikać zarówno z analizy tekstu przez samego Marszałka lub, co bardziej prawdopodobne, być efektem sugestii przedłożonych mu w formie ustnej lub pisemnej przez inne podmioty. Warunkiem sine qua non skierowania przez Marszałka Sejmu projektu ustawy do Komisji Ustawodawczej jest wcześniejsze zasięgnięcie przez niego opinii Prezydium Sejmu. Co warte podkreślenia, nie ma ona charakteru wiążącego, a zatem po jej uzyskaniu Marszałek Sejmu może albo odstapić od zamiaru skierowania projektu do wspomnianej komisji, albo skierować go do komisji w celu wydania opinii o jego dopuszczalności. W naszym przekonaniu de lege ferenda należałoby wzbogacić treść przepisów regulaminu Sejmu o postanowienia, które zobowiązywałyby Marszałka Sejmu do zwracania wnioskodawcy projektu ustawy, którego uzasadnienie nie

${ }^{13}$ Uchwała Sejmu RP z 30 lipca 1992 r. regulamin Sejmu Rzeczypospolitej Polskiej (t.jedn.: M.P. 2012, poz. 32 ze zm.).

${ }_{14}$ Tak G. Koksanowicz, Nadawanie biegu inicjatywom ustawodawczym w świetle postanowień regulaminu Sejmu, „Przegląd Prawa Konstytucyjnego” 2012, nr 1, s. 17-18.

${ }_{15}$ Por. M. Borski, Nadawanie biegu inicjatywom ustawodawczym - wybrane zagadnienia, „Przegląd Prawa Publicznego” 2015, nr 7-8, s. 155. 
odpowiada określonym regulaminowo wymogom. Takie rozwiązanie wydaje się uzasadnione, zważywszy na postępujące obniżanie się jakości wnoszonych projektów ustaw. Obowiązkiem Marszałka Sejmu jest m.in. stać na straży tworzenia „dobrego i efektywnego prawa”. Stąd też nawet jeżeli prawodawca nie zdecyduje się na skorzystanie z możliwości zmiany postanowień regulaminowych, należy oczekiwać od Marszałka Sejmu częstszego korzystania z przysługującej mu możliwości zwrotu projektu ustawy wnioskodawcy, w razie braku jego kompletności bądź poprawności. Aktualne rozwiązania w tym zakresie pokazuja, że to od aktywności Marszałka Sejmu zależy w znacznej mierze jakość stanowionego prawa.

\section{ZASTOSOWANIE INSTYTUCJI OBYWATELSKIEJ INICJATYWY USTAWODAWCZEJ W PRAKTYCE PARLAMENTARNEJ}

W tej części opracowania przedstawiono praktyczne aspekty zastosowania instytucji obywatelskiej inicjatywy ustawodawczej w praktyce parlamentarnej. Jak pokazują statystyki, zainteresowanie mechanizmem inicjatywy ustawodawczej wśród obywateli z każdym rokiem jest coraz większe. Od momentu jej wprowadzenia do zakończenia VII kadencji Sejmu zgłoszono 135 zawiadomień o utworzeniu obywatelskich komitetów inicjatywy ustawodawczej. Niestety zdecydowana większość z tych komitetów nie była jednak zdolna do wniesienia projektu ustawy. Jedynie 53 komitetom udało się wnieść skutecznie swój projekt pod obrady Sejmu. Przedmiotem szczegółowej analizy autorzy uczynili projekty ustaw obywatelskich wniesionych do Sejmu VI ${ }^{16}$ i VII ${ }^{17}$ kadencji.

W Sejmie VI kadencji do Marszałka Sejmu wpłynęło 19 obywatelskich projektów ustaw. Tylko w stosunku do 2 z nich proces legislacyjny zakończył się uchwaleniem ustawy. Były to: 1) ustawa z 5 stycznia 2011 r. o zmianie ustawy - Ordynacja wyborcza do rad gmin, rad powiatów i sejmików województw, ustawy - Ordynacja wyborcza do Sejmu Rzeczypospolitej Polskiej i do Senatu Rzeczypospolitej Polskiej oraz ustawy - Ordynacja wyborcza do Parlamentu Europejskiego ${ }^{18}$; 2) ustawa z 19 marca 2009 r. o zmianie ustawy o systemie oświaty oraz o zmianie niektórych innych ustaw ${ }^{19}$. Warto $\mathrm{w}$ tym miejscu zauważyć, że druga z uchwalonych ustaw stanowiła swego rodzaju „zbiór” propozycji obywatelskich i rządowych (rządowy projekt ustawy o zmianie ustawy o systemie oświaty oraz o zmianie niektórych innych ustaw ${ }^{20}$ ). Można zatem przyjać, że propozycje obywateli nie zostały uwzględnione w całości, lecz zostały w pewnym zakresie „połączone” z kontrpropozycjami rządowymi. Interesu-

\footnotetext{
165 listopada 2007 r. -7 listopada 2011 r.

178 listopada 2011 r. - 11 listopada 2015 r.

18 Dz. U. Nr 34, poz. 172.

19 Dz. U. Nr 56, poz. 458.

${ }^{20}$ Druk nr 1343.
} 
jące były także losy projektu ustawy zmieniającej samorządową ordynację wyborcza, a także ordynacje: do Sejmu i Senatu oraz Parlamentu Europejskiego. W październiku 2010 r. Obywatelski Komitet Inicjatywy Ustawodawczej „Czas na kobiety” skierował do Sejmu projekt ustawy „o zmianie ustawy - Ordynacji wyborczej do Sejmu Rzeczypospolitej Polskiej i Senatu Rzeczypospolitej Polskiej, ustawy - Ordynacja wyborcza do rad gmin, rad powiatów i sejmików województw oraz ustawy - Ordynacja wyborcza do Parlamentu Europejskiego, w związku z wprowadzeniem parytetu płci na listy kandydatów" ${ }^{21}$. W projekcie proponowano do wymienionej wyżej ordynacji dodać przepisy, które zakładałyby, że na liście wyborczej liczba kobiet nie może być mniejsza niż liczba mężczyzn. Wśród konstytucjonalistów pojawiły się wątpliwości, czy projekt tej ustawy jest zgodny z proklamowaną przez Konstytucję RP zasadą równości. Ponadto przeciwnicy projektu podnosili argument, że nie uściślono w nim dokładnej liczby kobiet na listach wyborczych, więc mogłyby one zajmować 50\% miejsc i więcej bez odgórnych ograniczeń. Pojawiły się również zastrzeżenia, że projekt ingeruje w autonomiczność partii politycznych, a przecież art. 11 Konstytucji RP zapewnia wolność tworzenia i działania partii politycznych w celu wpływania metodami demokratycznymi na kształtowanie polityki państwa ${ }^{22}$. Pierwsze czytanie ustawy w Sejmie odbyło się w styczniu 2010 r., a następnie projekt trafił do komisji. Wówczas Platforma Obywatelska zgłosiła poprawkę, zgodnie z którą kandydatki - kobiety i kandydaci - mężczyźni mieli stanowić po $35 \%$ osób na liście osób kandydujących w wyborach do Sejmu, Parlamentu Europejskiego i wyborach samorządowych. Ostateczne rozwiązanie przyjęte przez ustawodawce jest zatem swego rodzaju kompromisem i częściowo uwzględnia przyjęte przez projektodawcę rozwiązanie.

Pozostałe projekty ustaw zakończyły swój byt na różnych etapach postępowania ustawodawczego. Projekt ustawy o zmianie ustawy o planowaniu rodziny, ochronie płodu ludzkiego i warunkach dopuszczalności przerywania ciąży oraz niektórych innych ustaw trafił do I czytania na posiedzeniu Sej$\mathrm{mu}$, następnie trafił do prac komisyjnych, jednakże ze względu na negatywna opinię został w III czytaniu odrzucony ${ }^{23}$. Była to jedna z wielu prób przeforsowania całkowitego zakazu aborcji, która w ówczesnych uwarunkowaniach politycznych skazana była na niepowodzenie, ale stanowiła ważny argument dla środowiska antyaborcyjnego, które wykorzystało odrzucenie projektu obywatelskiego jako argument w dalszej walce politycznej.

Obywatelskie projekty ustaw o: działalności spółdzielni mieszkaniowych ${ }^{24}$ oraz zmianie ustawy - Kodeks karny ${ }^{25}$, a także dwa obywatelskie projekty

${ }^{21}$ Obywatelski projekt ustawy - o zmianie ustawy - Ordynacja wyborcza do Sejmu Rzeczypospolitej Polskiej i Senatu Rzeczypospolitej Polskiej, ustawy - Ordynacja wyborcza do rad gmin, rad powiatów i sejmików wojewódzkich oraz ustawy - Ordynacja wyborcza do Parlamentu Europejskiego, w związku z wprowadzeniem parytetu płci na listach kandydatów, druk sejmowy nr 2713.

${ }^{22}$ Por. A. Szmyt, Opinie w sprawie wprowadzenia parytetu ptci na listach wyborczych, „Przegląd Sejmowy" 2010, nr 3, s. 137.

${ }^{23}$ Druk nr 4222.

${ }^{24}$ Druk nr 3317.

${ }^{25}$ Druk nr 2249. 
ustaw o przywróceniu dnia wolnego od pracy w Święto Trzech Króli ${ }^{26}$ zostały odrzucone już na etapie I czytania. Z kolei obywatelski projekt ustawy o zmianie ustawy o dochodach jednostek samorządu terytorialnego ${ }^{27}$ został skierowany do I czytania, które jednak nie odbyło się ze względu na zakończenie kadencji Sejmu. Projekt ten w VIII kadencji Sejmu trafił już ${ }^{28}$ do prac komisyjnych $^{29}$.

Projekt ustawy o działalności spółdzielni mieszkaniowych autorstwa związków rewizyjnych spółdzielni mieszkaniowych zakładał m.in. zmianę zasad finansowych wykupu mieszkań lokatorskich, znosił obowiązek zwoływania walnych zgromadzeń spółdzielców, redukował do minimum kontrolę spółdzielców nad poczynaniami władz spółdzielni. Znosił też ograniczenia czasowe dotyczace sprawowania funkcji przez ten sam zarząd oraz wprowadzał odpłatność za zasiadanie w radach nadzorczych spółdzielni. Większość sejmowa uznała, że zaproponowane rozwiązania mają się nijak do współczesnych wyzwań stojących przed spółdzielczością mieszkaniową i cofają ją do czasów PRL, gdy własność prywatna była zwalczana ze względów ideologicznych. Niektórzy posłowie wprost zauważali, że projekt ten dyskwalifikuje sam fakt, że przygotowały go związki rewizyjne spółdzielni mieszkaniowych. Podczas debaty posłowie koalicji PO-PSL podnosili również, że trwaja prace nad nowelizacją ustawy o spółdzielniach mieszkaniowych i Prawa spółdzielczego, które przygotowane są z udziałem prawników, ekspertów w dziedzinie prawa spółdzielczego. Nowelizacje te mają uporządkować przepisy dotyczące spółdzielczości mieszkaniowej i wypełnić wszelkie luki prawne.

W pozostałych przypadkach ustawodawca zastosował najbardziej „elegancka” metodę „topienia” obywatelskich projektów ustaw - pozostawienie ich, po skierowaniu do prac komisyjnych, w komisjach sejmowych i w ten sposób wyeliminowanie ich. W Sejmie VII kadencji do Marszałka Sejmu wpłynęło 28 projektów ustaw. Spośród nich jedynie w przypadku 2 ustaw proces ustawodawczy zakończył się sukcesem. Były to: 1) ustawa z 20 marca 2015 r. o zmianie ustawy - Prawo budowlane oraz niektórych innych ustaw ${ }^{30}$ oraz 2) ustawa z 13 grudnia 2013 r. o rodzinnych ogrodach działkowych ${ }^{31}$.

Bardzo ciekawe były zwłaszcza losy projektu ustawy o rodzinnych ogrodach działkowych. Projekt ten miał na celu uregulowanie w sposób kompleksowy kwestii rodzinnych ogrodów działkowych oraz statusu prawnego działkowców w związku z wyrokiem Trybunału Konstytucyjnego. Warto zauważyć, że Komitetowi Inicjatywy Ustawodawczej Projektu Ustawy o Rodzinnych Ogrodach Działkowych udało się zgromadzić blisko milion podpisów. Oznaczało to ogromna mobilizację środowiska działkowców. Do prac komisyjnych zostały skierowane łacznie 4 projekty: obywatelski oraz projekty: PO, SLD i Solidar-

\footnotetext{
26 Druki nr 2063 i 826.

27 Druk nr 4639.

28 Stan na 25 listopada 2016 r.

29 Druk nr 24.

${ }^{30}$ Dz. U. 2015, poz. 528.

31 Dz. U. 2014, poz. 40.
} 
nej Polski ${ }^{32}$. Podczas prac podkomisji, która została powołana do rozpatrzenia wymienionych projektów, zdecydowano, że to obywatelski projekt będzie głównym w pracach nad nową ustawa. Do projektu złożono blisko 250 poprawek, ale ostatecznie ustawa została uchwalona i stała się obowiązującym prawem. Można więc uznać, zwłaszcza biorac pod uwagę skalę poparcia społecznego dla tej ustawy, że okazała się ona dużym sukcesem wnioskodawców. Według nich dobro ludzi - działkowców - zwyciężyło w walce z deweloperami i innymi grupami interesu, którzy na ogrody działkowe patrzą jedynie przez pryzmat ich wartości finansowej.

Szczególny przypadek dotyczył ustawy z 10 maja 2013 r. o okręgach sądowych sądów powszechnych ${ }^{33}$. Ustawa ta była konsekwencją reformy dotyczącej sądów rejonowych, przeprowadzonej rozporządzeniem ówczesnego ministra sprawiedliwości Jarosława Gowina. Na jej mocy 79 najmniejszych sądów rejonowych o limicie etatów do dziewięciu sędziów stało się wydziałami zamiejscowymi większych jednostek. Reforma ta - jeszcze na etapie jej planowania - wywołała liczne protesty środowiska sędziowskiego; krytykowały ją i opozycja, i PSL. Aby ją znieść, przygotowany został (pilotowany w Sejmie przez PSL) obywatelski projekt ustawy przywracajacej stan prawny sprzed reformy. Sejm uchwalił tę ustawę, Senat podjął uchwałę o jej odrzuceniu w całości, następnie większość posłów odrzuciła stanowisko senackie i ustawa trafiła do prezydenta. Ten zdecydował się na skorzystanie z prawa weta, w jego ocenie, bowiem „[...] miała ona wewnętrzne wady i sprzeczności, które ją w pełni dyskwalifikowały jako ewentualne narzędzie skutecznego działania na rzecz przywrócenia choćby jednego sądu rejonowego”. Przy okazji prezydent Bronisław Komorowski mocno skrytykował posłów, twierdząc, że „To jest rzecz wstydliwa, że tego rodzaju projekt przechodzi przez parlament, dochodzi do prezydenta, który musi się do niego ustosunkować, podczas gdy wszyscy od początku do końca wiedzieli, że jest to projekt z wadami tak poważnymi, że go to dyskwalifikuje. W naszym przekonaniu ten projekt nie powinien w ogóle być głosowany w Sejmie”. Weto prezydenta okazało się skuteczne, ustawa bowiem nie została ponownie uchwalona przez Sejm.

Natomiast obywatelskie projekty ustaw o: zmianie ustawy o uprawnieniach do bezpłatnych i ulgowych przejazdów środkami publicznego transportu zbiorowego ${ }^{34}$; zmianie ustawy o systemie oświaty ${ }^{35}$; zmianie ustawy o planowaniu rodziny, ochronie płodu ludzkiego i warunkach dopuszczalności przerywania ciąży ${ }^{36}$; projekt ustawy „Wolna Niedziela” o zmianie ustawy - Kodeks pracy $^{37}$; zmianie ustawy z 6 czerwca 1997 r. - Kodeks karny ${ }^{38}$; zmianie ustawy o systemie oświaty oraz niektórych innych ustaw ${ }^{39}$; zmianie ustawy - Kodeks

\footnotetext{
32 Druki nr: 1148, 1170 i 1240.

33 Druk nr 804.

${ }^{34}$ Druk nr 18.

35 Druk nr 895.

${ }^{36}$ Druk nr 1654.

37 Druk nr 2113.

38 Druk nr 2654.

39 Druk nr 3177.
} 
wyborczy oraz niektórych innych ustaw ${ }^{40}$; zmianie ustawy o planowaniu rodziny, ochronie płodu ludzkiego i warunkach dopuszczalności przerywania ciąży oraz niektórych innych ustaw ${ }^{41}$ - zostały odrzucone już na etapie I czytania.

Z kolei obywatelskie projekty ustaw o: zachowaniu przez Państwo Polskie większościowego pakietu akcji Grupy Lotos $\mathrm{SA}^{42}$; zmianie ustawy o systemie oświaty i ustawy o zmianie ustawy o systemie oświaty oraz niektórych innych ustaw $^{43}$ - wprawdzie trafiły do I czytania na posiedzeniu Sejmu, a następnie do prac komisyjnych, jednakże ze względu na negatywną opinię zostały w III czytaniu odrzucone.

Niepowodzeniem zakończył się też obywatelski projekt ustawy o zmianie ustawy o ochronie zwierząt ${ }^{44}$, i to już na etapie I czytania, marszałek Sejmu bowiem przeniosła na kolejne posiedzenie głosowanie nad wnioskiem o odrzucenie projektu ustawy w I czytaniu. Głosowanie to nigdy się nie odbyło.

Nieskuteczny okazał się też obywatelski projekt ustawy o zmianie ustawy o podatku dochodowym od osób fizycznych, który został wycofany przez Komitet Obywatelskiej Inicjatywy Ustawodawczej „Razem” na skutek wprowadzenia z inicjatywy rządowej postulowanych przez komitet zmian ${ }^{45}$. Projekt ten miał na celu znowelizowanie przepisów dotyczacych podstawy obliczenia podatku dochodowego od osób fizycznych w zakresie odliczenia od dochodu kwot wpłat dokonanych przez podatnika $\mathrm{w}$ danym roku podatkowym bezpośrednio na własne dobrowolne zabezpieczenie emerytalne w instytucjach finansowych nadzorowanych (lub notyfikowanych) przez Komisję Nadzoru Finansowego. Wydaje się, że mimo formalnego wycofania projektu ustawy przez wnioskodawców odnieśli oni sukces, wprowadzenie bowiem zmian z inicjatywy Rady Ministrów zostało zainspirowane właśnie ich projektem.

W przypadku obywatelskiego projektu ustawy o zmianie ustawy o zaopatrzeniu emerytalnym funkcjonariuszy Policji, Agencji Bezpieczeństwa Wewnętrznego, Agencji Wywiadu, Służby Kontrwywiadu Wojskowego, Służby Wywiadu Wojskowego, Centralnego Biura Antykorupcyjnego, Straży Granicznej, Biura Ochrony Rządu, Państwowej Straży Pożarnej i Służby Więziennej oraz ich rodzin oraz niektórych innych ustaw ${ }^{46}$ też nie doszło do skutecznego przeprowadzenia procesu legislacyjnego; projekt został wprawdzie skierowany do I czytania, jednakże na skutek zakończenia kadencji Sejmu nie odbyło się ono. Projekt ten został ostatecznie uchwalony w bieżącej, VIII kadencji Sejmu ${ }^{47}$. W pozostałych przypadkach projekty ustaw zakończyły swój byt na etapie prac komisyjnych.

Warto odnotować, że w przypadku obywatelskiego projektu ustawy o zmianie ustawy o ochronie przyrody odbyło się wysłuchanie publiczne ${ }^{48}$. Stanowi

\footnotetext{
${ }^{40}$ Druk nr 3248.

41 Druk nr 3806.

42 Druk nr 24.

43 Druk nr 27.

44 Druk nr 2349.

${ }^{45}$ Druk nr 25.

${ }_{46}$ Druk nr 3985.

47 Druk nr 30.

48 Druk nr 23.
} 
ono ważny instrument demokracji partycypacyjnej i jest zdecydowanie zbyt rzadko wykorzystywane w praktyce parlamentarnej. Tym bardziej zastosowanie tego mechanizmu w procedowaniu obywatelskiego projektu ustawy (mimo zakończenia postępowania ustawodawczego w tym zakresie na etapie prac komisyjnych) należy ocenić bardzo pozytywnie.

Analiza procedowanych w trybie obywatelskiej inicjatywy ustawodawczej projektów wskazuje, że projekty te, podobnie jak projekty „ustaw zwykłych”, zawierały na etapie ich składania do Marszałka Sejmu informację, co do ich zgodności z prawem Unii Europejskiej (albo że nie są objęte zakresem prawa Unii Europejskiej) oraz dane o skutkach prawno-społeczno-gospodarczych. Warto jednak zauważyć, że informacje te były na różnym poziomie szczegółowości. Tytułem przykładu uzasadnienie obywatelskiego projektu ustawy o zmianie ustawy o dochodach jednostek samorządu terytorialnego ${ }^{49}$ zawierało na 12 stronach maszynopisu kompletne określenie celu ustawy, szczegółowo przedstawione dane o skutkach prawno-społeczno-gospodarczych, a także oświadczenie, że projektowana regulacja nie jest objęta prawem Unii Europejskiej. Bardzo solidnie zostało także przygotowane uzasadnienie projektu ustawy zmieniającej ustawę o ochronie zwierząt ${ }^{50}$. Zmianie podlegały w praktyce tylko dwa ustępy, uzasadnienie jednak liczyło blisko 10 stron zawierających bardzo szczegółowo omówiony wpływ tych zmian na rynek pracy, konkurencyjność gospodarki czy też na sytuację i rozwój regionalny. W przypadku tej ustawy można także pochwalić wszechstronnie przeprowadzony proces konsultacji społecznych.

Zupełnie inny poziom szczegółowości można dostrzec w przypadku nowelizacji ustawy o systemie oświaty oraz niektórych innych ustaw ${ }^{51}$. Była to daleko idąca zmiana ustawy o systemie oświaty (zmianie podlegało 25 różnych przepisów tej ustawy), tymczasem uzasadnienie udało się zmieścić na czterech stronach maszynopisu.

Z kolei przykładu bardzo niestarannie przygotowanego uzasadnienia projektu ustawy dostarcza projekt ustawy o działalności spółdzielni mieszkaniowych ${ }^{52}$. Wzbudził on poważne watpliwości ówczesnego marszałka Sejmu Bronisława Komorowskiego, który w piśmie skierowanym do Jerzego Jankowskiego (pełnomocnika Komitetu Inicjatywy Ustawodawczej projektu ustawy o działalności spółdzielni mieszkaniowej53) zwrócił uwagę na następujące braki w uzasadnieniu tego projektu stanowiace naruszenie procedury ustawodawczej: niewskazanie skutków finansowych wykonania ustawy, niewyjaśnienie potrzeby i celu wydania ustawy, niewskazanie skutków społecznych, gospodarczych, finansowych i prawnych, nieprzedłożenie oświadczenia o zgodności projektu ustawy z prawem Unii Europejskiej albo oświadczenia, że przedmiot projektowanej regulacji nie jest objęty prawem unijnym, brak

${ }^{49}$ Druk nr 4639 - VI kadencja Sejmu.

${ }^{50}$ Druk nr 2349 - VII kadencja Sejmu.

${ }^{51}$ Druk nr 895 - VII kadencja Sejmu.

${ }^{52}$ Druk nr 3317 - VI kadencja Sejmu.

${ }_{53}$ Pismo z 3 marca 2010 r., BPSP-020-2(5)/10, <http://orka.sejm.gov.pl/Druki6ka.nsf/0/F7A27943EF81928EC1257775003C92E4/\$file/3317.pdf>. 
wymaganych opinii trzech podmiotów. Biorąc powyższe pod uwagę, marszałek Sejmu wezwał ww. pełnomocnika do uzupełnienia tych braków w terminie 14 dni. Dopiero po dokonaniu niezbędnych uzupełnień projektowi ustawy został nadany bieg.

Należy też zwrócić też uwagę, że żaden $\mathrm{z}$ analizowanych projektów ustaw nie zawierał oceny skutków regulacji po wniesieniu do niego poprawek w kolejnych stadiach postępowania ustawodawczego, co oznacza, że brak aktualizacji skutków proponowanej regulacji. Przyjęty model oceny skutków regulacji odnosi się bowiem wyłacznie do projektu wnoszonego do Sejmu, a nie do uchwalanej ustawy.

\section{PODSUMOWANIE}

W świetle przedstawionej analizy procedowanych w trybie obywatelskiej inicjatywy ustawodawczej projektów ustaw można sformułować wniosek, że projekty te spełniały kryteria stawiane „ustawom zwykłym”, gdyż zawierały zarówno informację odnośnie do kwestii ich zgodności z prawem Unii Europejskiej (albo że nie sa objęte zakresem prawa Unii Europejskiej), jak i dane o skutkach prawno-społeczno-gospodarczych. Dane te - w zależności od projektu - były jednak na różnym poziomie szczegółowości. Natomiast analizowane projekty ustaw, podobnie zreszta jak projekty ustaw wnoszone przez innych wnioskodawców, nie zawierały oceny skutków na poziomie poprawek w procesie legislacyjnym. Brak tego typu informacji może skłaniać do refleksji nad stanem poprawności tworzenia ocen skutków regulacji. W naszym przekonaniu funkcjonujaccy model oceny skutków regulacji jest nieefektywny, a zarazem nierzetelny, skoro odnosi się wyłącznie do projektu wnoszonego do Sejmu. Zatem w odniesieniu do obywatelskiego projektu ustawy zasadne wydaje się zaproponowanie nałożenia na Marszałka Sejmu obowiązku aktualizacji kosztów końcowych w przypadku wprowadzenia poprawek i przedstawienia całkowitych kosztów przed podejmowaniem przez Sejm decyzji o uchwaleniu ustawy ${ }^{54}$. Niezależnie od powyższego obowiązek przeprowadzenia konsultacji oraz uzyskania wymaganych prawem opinii spoczywać powinien nie na komitecie inicjatywy ustawodawczej, lecz na Marszałku Sejmu ${ }^{55}$. Brak zwolnienia inicjatorów projektów obywatelskich z obowiązku przeprowadzenia konsultacji, względnie uzyskania opinii podmiotów dysponujacych prawem zajęcia stanowiska w sprawie materii, której projekt dotyczy, blokuje bowiem oddolne projekty obywatelskie ${ }^{56}$.

${ }^{54}$ Szerzej M. Borski, R. Glajcar, B. Przywora, op. cit., s. 221-222.

55 Por. M. Borski, Inicjatywa ludowa instrumentem presji na prawodawcę?, „Przegląd Prawa Publicznego" 2016, nr 7-8, s. 61.

56 Szerzej na ten temat zob. A. Rytel-Warzocha, P. Uziębło, Inicjatywa ustawodawcza obywateli jako instrument bezpośredniej partycypacji społecznej, w: eidem, M. Herrmann (red.), Obywatele decyduja. Obywatelska inicjatywa ustawodawcza, jako narzędzie kształtowania postaw obywatelskich, Łódź 2012, s. 39-40. 
Oczywiście do kwestii korzystania przez grupy obywateli z prawa inicjatywy ustawodawczej należy podchodzić racjonalnie, pamiętając, że sformalizowana procedura postępowania z projektem ustawy, a następnie z ustawa, w Sejmie i w Senacie daje pewne możliwości sanowania niedociagnięć legislacyjno-technicznych wnoszonych projektów ustaw, oczywiście w granicach określonych znaczeniem i funkcją poszczególnych etapów postępowania ustawodawczego w parlamencie.

Z przeprowadzonej analizy projektów wyłania się podstawowy problem: słaba skuteczność obywatelskich inicjatyw ustawodawczych. W tym zakresie można dostrzec trudności pojawiające się zarówno na etapie wstępnym (rejestracji komitetu), jak i późniejszych, szczególnie zbyt krótki (3-miesięczny) termin na zebranie wymaganych podpisów pod przygotowanym projektem ustawy. Z przywołanych statystyk wynika, że w obecnym kształcie instytucja ta jest stosunkowo mało skuteczna. Należy zatem zastanowić się, jak wzmocnić skuteczność obywatelskiej inicjatywy, aby konstrukcja normatywna obywatelskiej inicjatywy ustawodawczej rzeczywiście służyła uruchamianiu sprawnego i jednocześnie efektywnego ustawodawstwa i aby prowadziła do zwiększenia wpływu obywateli na proces ustawodawczy. W naszym przekonaniu zmiany legislacyjne powinny pójść w kilku kierunkach.

Przede wszystkim na organach państwowych spoczywać winien obowiązek pomocy komitetom w przygotowaniu uzasadnienia projektu ustawy, szczególnie w zakresie oceny skutków regulacji. Komitety obywatelskie nie posiadaja odpowiedniego, profesjonalnego aparatu urzędniczego, jak inni wnioskodawcy, np. Rada Ministrów czy Prezydent RP. Warto w tym miejscu zauważyć, że podczas prac nad ustawą o wykonywaniu inicjatywy ustawodawczej przez obywateli odrzucono poprawkę Senatu zobowiązujaca organy administracji państwowej do pomocy przy przygotowywaniu uzasadnienia projektu obywatelskiego ${ }^{57}$. W naszym przekonaniu przyjęcie tego rozwiązania ułatwiłoby znacznie komitetom inicjatywy przygotowywanie profesjonalnych uzasadnień zgłaszanych przez nie projektów ustaw.

Kolejny kierunek zmian to problem przygotowywania oceny skutków regulacji (OSR), dokonywanej w odniesieniu do projektów ustaw, szczególnie na etapie wnoszenia poprawek $\mathrm{w}$ toku prac ustawodawczych. W praktyce niejednokrotnie czytelnik OSR nie wie, który podmiot prywatny i jakie korzyści finansowe ma odnieść z tytułu nowej regulacji ani też kto i jakie koszty ma ponieść celem wdrożenia projektowanych rozwiązań. Biorąc to pod uwagę, nie sposób oprzeć się refleksji, że taki stan regulacji dotyczących OSR jest zabiegiem celowym, który służy w pewnym stopniu ukrywaniu przed opinią publiczną rzetelnych informacji na temat kosztów całkowitych ustaw. W procesie legislacyjnym kluczową rolę odgrywa Marszałek Sejmu. W razie zaistnienia

${ }^{57} \mathrm{~W}$ myśl tej poprawki proponowano: Organy administracji państwowej obowiązane sa, na żądanie pełnomocnika komitetu, udzielić pomocy przy określaniu skutków finansowych wykonania projektu ustawy. Por. <http://orka.sejm.gov.pl/Rejestrd.nsf/wgdruku/1140/\$file/1140.pdf> [dostęp: 9.11.2017]. 
poważnych uchybień wynikających z zasad tworzenia prawa, a do takich należy zaliczyć nierzetelne przygotowanie OSR, wszystkie projekty ustaw powinny być przez Marszałka Sejmu zwracane do uzupełnienia. Wydaje się, że takie konsekwentne działanie Marszałka Sejmu przyczyniłoby się do poprawy jakości stanowionego prawa i jego uporządkowania przez wyeliminowanie niepotrzebnych regulacji. Pod rozwagę można poddać postulat wprowadzenia do regulaminu Sejmu przepisów obligujących Marszałka Sejmu do zwracania wnioskodawcy projektu ustawy, którego uzasadnienie nie odpowiada w pełni określonym regulaminowo wymogom. Obecnie jest to uprawnienie wyłącznie o charakterze fakultatywnym.

Rozważenia wymagają też zmiany w zakresie dotyczącym zasady dyskontynuacji w odniesieniu do projektów obywatelskich. Wprawdzie ustawodawca przesądził, że projekt ustawy, w stosunku do którego postępowanie ustawodawcze nie zostało zakończone w trakcie kadencji Sejmu, w której został wniesiony, jest rozpatrywany przez Sejm następnej kadencji bez potrzeby ponownego wniesienia projektu ustawy, jednakże wydaje się, że rozwiązanie to nie jest wystarczające. W przypadku gdy Sejm następnej kadencji (a więc następującej po kadencji, w której projekt został wniesiony) również nie ukończy prac nad projektem, inicjatywa ustawodawcza obywateli przepada - Sejm kolejnej kadencji nie ma bowiem obowiązku kontynuowania prac nad projektem. Tak więc wyjątek od zasady dyskontynuacji działa tylko w kadencji następującej bezpośrednio po kadencji, w której obywatelski projekt został wniesiony. Duża waga, jaka przywiąuje ustawodawca do kwestii obywatelskiej inicjatywy ustawodawczej, powinna - naszym zdaniem - znaleźć odzwierciedlenie w bardziej kategorycznym i całkowitym wyłączeniu stosowania zasady dyskontynuacji w stosunku do tych projektów. Postępowanie z obywatelskim projektem ustawy powinno być zatem kontynuowane nie tylko w najbliższej po wniesieniu projektu do Sejmu kadencji, ale także w kolejnych kadencjach bez jakichkolwiek ograniczeń.

Kolejne zmiany powinny pójśś w kierunku wydłużenia terminu na zebranie wymaganych podpisów pod przygotowanym projektem ustawy, np. do 6 miesięcy. Nie ulega wątpliwości, na co wskazuje praktyka, że termin 3 miesięcy jest zbyt krótki na zebranie 100000 podpisów i nie pozwala obywatelom na skuteczne występowanie z inicjatywą ustawodawcza. Warto także, naszym zdaniem, rozważyć nowelizację ustawy o obywatelskiej inicjatywie ustawodawczej idąca w kierunku gromadzenia podpisów pod obywatelskim projektem ustawy za pośrednictwem Internetu (system zbierania deklaracji online) ${ }^{58}$. Odformalizowałoby to obecne trochę już anachroniczne rozwiązanie wymagające złożenia własnoręcznego podpisu na wykazie wraz z podaniem imienia i nazwiska, miejsca zamieszkania i numeru PESEL w miejscu zbierania pod-

${ }^{58}$ Pogłębione rozważania na ten temat można znaleźć w ekspertyzie przygotowanej na zlecenie Instytutu Spraw Obywatelskich przez P. Waglowskiego, Elektroniczne poparcie inicjatyw obywatelskich, Warszawa $2015<\mathrm{https}$ ://inspro.org.pl/ekspertyza-elektroniczne-poparcie-inicjatyw-obywatelskich> [dostęp: 9.11.2017]. 
pisów, w którym wyłożony jest projekt ustawy. Jednocześnie na pewno wymóg dotyczacy zebrania 99 tysięcy podpisów w ciagu 3 miesięcy nie byłby już tak trudny do zrealizowania. Rozwiązanie to niewątpliwie zwiększyłoby dynamikę procesów społecznych i wpłynęłoby pozytywnie na zwiększenie presji obywateli na prawodawcę.

Nie ulega naszym zdaniem wątpliwości, że zmiany aktualnej regulacji powinny wiązać się ze zwiększeniem wpływu obywateli na sam proces legislacyjny. W obecnym brzmieniu ustawa o wykonywaniu inicjatywy ustawodawczej przez obywateli nie przewiduje obowiązku zakończenia prac legislacyjnych nad projektem w określonym terminie ani żadnych innych szczegółowych wymogów dotyczących dalszego przebiegu procesu legislacyjnego w tym zakresie. Dlatego też niezbędne wydaje się wprowadzenie obowiązku przeprowadzenia wysłuchania publicznego po zakończeniu I czytania projektu. Biorąc pod uwagę wszystkie obywatelskie projekty ustaw rozpatrywane przez Sejm VI i VII kadencji, wysłuchanie publiczne przeprowadzone zostało tylko w odniesieniu obywatelskiego projektu ustawy o zmianie ustawy o ochronie przyrody ${ }^{59}$. Należy przy tym zwrócić uwagę na fakt, że obecnie podjęcie uchwały o przeprowadzeniu wysłuchania publicznego zależy od decyzji komisji, w której projekt jest rozpatrywany. W naszej ocenie obligatoryjne wysłuchanie publiczne w odniesieniu do obywatelskich projektów ustaw pozwoli obywatelom (a nie tylko wnioskodawcom) na przedstawienie poglądów na temat danego projektu ustawy. Ponadto takie rozwiązanie pozwoli ograniczyć pochopne odrzucanie obywatelskich projektów już w I czytaniu. Wartym rozważenia rozwiązaniem jest także zwiększenie transparentności procesu ustawodawczego, co w konsekwencji zwiększy nad nim kontrolę obywateli. Naszym zdaniem można to osiągnąć przez ścisłe określenie terminów wiążących ustawodawcę.

\section{dr Maciej Borski}

Wyższa Szkoła Humanitas w Sosnowcu

maciej.borski@humanitas.edu.pl

dr Bogustaw Przywora

Uniwersytet Humanistyczno-Przyrodniczy im. Jana Dtugosza w Częstochowie

b.przywora@ajd.czesto.pl

CIVIL LEGISLATIVE INITIATIVE IN THE POLISH LEGAL ORDER - AN ATTEMPT OF ITS ASSESSMENT FROM THE PERSPECTIVE OF PARLIAMENTARY PRACTICE

\section{Summary}

The aim of this article is to present and evaluate the legal regulations concerning a bill initiated by citizens from the perspective of the practice of its application. This issue does not have a theoretical dimension only, but is also of significant practical importance, because an interest in this legal mechanism amongst citizens is increasing rapidly and influences the shape of the

${ }^{59}$ Druk nr 23 - VII kadencja Sejmu. 
civil society. The problem that continues to exist are numerous barriers or regulations governing parliamentary works that make it difficult for citizens to use the right to initiate bills that is constitutionally guaranteed. They range from the requirement to register the committee at the initial stage to the final stage of parliamentary work on the project. In the concluding part of the article some proposals of the necessary amendments to the existing regulations governing the civil right of legislative initiative are made. 
